\title{
CONTROL OF GRAPEVINE DECLINE WITH THE USE OF DRAINS AND RIDGES ${ }^{1}$
}

\author{
REMI NATALIN DAMBROS ${ }^{2}$, MARCO ANTONIO DALBÓ 3 , \\ CRISTIANO JOÃO ARIOLI ${ }^{4}$, MILTON DA VEIGA
}

ABSTRACT - The incidence of grapevine decline and dye back is quite severe in grapevine-growing regions of southern Brazil, especially in the Midwest of the State of Santa Catarina. Field studies on problematic areas identified the presence of the Brazilian ground pearl or margarodes (Eurhizococcus brasiliensis Hempel) and soil fungi (Cylindrocarpon, Fusarium and others) associated with the disease. Soil characteristics such as high clay content and poor aeration were associated with the problem. To evaluate the effect of pre-planting tillage in reducing the incidence of grapevine decline, an experiment was carried out with two rootstocks and three pre-planting tillage (regular plowing, drains, and ridges) in an area where high plant mortality had been previously observed. Pre-planting tillage with the use of ridges along the rows gave the best results with a drastic reduction in the decline incidence. The number of ground pearl cysts was unaffected by pre-planting tillage and did not relate with the incidence of decline and death of plants.

Index terms: Vitis sp., rootstocks, black foot disease, ground pearl.

\section{CONTROLE DO DECLÍNIO DA VIDEIRA COM O USO DE DRENOS E CAMALHÕES}

RESUMO - A incidência de declínio e morte de plantas de videira é bastante comum nas regiões vitícolas do Sul do Brasil, especialmente no Vale do Rio do Peixe-SC. Estudos de campo realizados em áreas com grande incidência identificaram a presença de pérola-da-terra (Eurhizococcus brasiliensis Hempel) e fungos de solo (Cylindrocarpon, Fusarium e outros) associados à doença. Observou-se também que características de solo, como alta percentagem de argila e deficiência de aeração, estavam associadas ao problema. Para avaliar o efeito de sistemas de preparo do solo em pré-plantio na redução do declínio e morte de plantas de videira, implantou-se um experimento fatorial com dois porta-enxertos e três sistemas de preparo do solo em pré-plantio (preparo regular e confecção de drenos e camalhões) em área com histórico de alta mortalidade de plantas. A confecção de camalhões na linha de plantio proporcionou os melhores resultados, com redução significativa da incidência de declínio. O número de cistos de pérola-da-terra foi pouco afetado pela confecção de drenos ou de camalhões e não se correlacionou com a incidência de declínio e morte de plantas.

Termos para indexação: Vitis sp., porta-enxerto, pérola-da-terra, pé-preto.

${ }^{1}$ (Trabalho 028-15). Recebido em: 09-01-2015. Aceito para publicação em: 17-08-2015.

${ }^{2}$ Pesquisador da Epagri - Estação Experimental de Videira-SC. E-mail: remi@epagri.sc.gov.br

${ }^{3}$ Pesquisador da Epagri - Estação Experimental de Videira-SC. E-mail: dalbo@epagri.sc.gov.br

${ }^{4}$ Pesquisador da Epagri - Estação Experimental de São Joaquim-SC. E-mail: cristianoarioli@epagri.sc.gov.br

${ }^{5}$ Pesquisador da Epagri - Estação Experimental de Campos Novos-SC. E-mail: mveiga@epagri.sc.gov.br 


\section{INTRODUCTION}

The incidence of decline and death of vine plants is one of the most serious problems of viticulture in Brazil, having been responsible for the elimination of many vineyards in the main producing regions (SCHUCK et al., 2001; BOTTON et al., 2000; GARRIDO et al., 2004a). The causes of this problem seem to be multiple, including the attack of the Brazilian ground pearl or margarodes (Eurhizococcus brasiliensis Hempel), soil fungi and other causes of stress for plants. The problem shows itself particularly serious in young plants, which prevents the establishment of new vineyards in some places.

The decline and death of young plants have been reported in several countries and attributed mainly to the attack of fungi from the genus Cylindrocarpon ("black-foot"), Phaeoacremonium and Phaeomoniella (Petri disease) (HALEEN et al., 2006; GUBLER at al., 2004). In these locations, environmental factors causing plant stress, such as problems of handling and compaction or poordraining soil are related to the disease development (HALEEN et al., 2007). These factors are also associated with vine decline in Brazil (GARRIDO et al., 2004b).

In the Vale do Rio do Peixe region, in the Midwest of the State of Santa Catarina, there is also evidence that the physical conditions of the soil are related to the decline of the vine, but with the added difficulty that the presence of ground pearl apparently enhances the action of pathogenic fungi because of damage caused in the roots (DALBÓ et al., 2012). In this region, the smooth plain soils with higher clay content (Oxisols) are showing higher rates of mortality, whereas in gravelly soils (Cambisols), with better natural drainage, problems are generally smaller. Another feature observed in the vineyards of this region is that even in deep soil, the root system is very shallow, with a small percentage of roots exceeding $40 \mathrm{~cm}$ in depth. The lack of aeration is the most likely cause for restriction to deep root system growth (DALBÓ et al., 2011).

Measures that have been used to reduce the vine decline primarily involve the use of neonicotinoid insecticides applied to the soil for control of the ground pearl. This practice has satisfactory efficiency only in the case of young plants (BOTTON et al., 2010). The use of more resistant rootstocks against decline has been a way to reduce the problem (BOTTON; COLLETA, 2010; DALBÓ et al., 2012). Another measure that has proved effective is preparing the ground for pre- planting with the use of trenches or drains, which improves the conditions of drainage and soil aeration (DALBÓ et al., 2007). These three alternatives were studied at different locations in the Vale do Rio do Peixe, SC, and all of them had some effect in reducing the incidence of vine decline. Notwithstanding, none of the alternatives provided satisfactory results when isolated (DALBÓ et al., 2007).

More intensive soil preparation systems in pre-planting have been used to circumvent the problem, for instance, the opening of trenches in the rows with the help of bulldozers. However, the opening of trenches is difficult and costly to run and can result in water accumulation inside when not associated with subsurface drainage. Making ridges along the row is an alternative soil preparation that can provide similar results to the opening of trenches by the fact that it increases the volume of soil with good drainage and aeration, which would act as a safe zone for the roots. The ridges are recommended both to facilitate the cultivation of the vine in areas with drainage problems and to increase the depth of shallow soils or with other physical or chemical restraints in the basement (KIRCHHOF et al., 1991; MYBURGH and MOOLMAN, 1991; CONRADIE et al., 2002; WHEATON et al., 2008). Veiga et al. (2012) observed improvements in chemical and physical properties with different depths in the ridges, which were attributed to moving the surface layer of soil between rows to the crop row. This provided greater uniformity in attributes between layers sampled down to $40 \mathrm{~cm}$ depth.

This study was conducted to assess the effect of making drains and/or ridges on the development and incidence of decline in two vine rootstocks in areas where high incidence of plant mortality had been previously observed.

\section{MATERIAL AND METHODS}

The experiment was conducted in the area of the Epagri - Videira Experiment Station, Videira, SC $\left(27^{\circ} 02^{\prime} 24^{\prime \prime} \mathrm{S}, 51^{\circ} 08^{\prime} 05^{\prime} \mathrm{W}\right.$, and altitude $834 \mathrm{~m}$ ). The soil is classified as Dystrophic Red Latosol according to the Brazilian System of Soil Classification (EMBRAPA, 2004), an Oxisol according to Soil Taxonomy (SOIL SURVEY STAFF, USDA, 2006), and presented at the site of the experiment an average slope of $10 \%$. The clay content ranged between 610 and $646 \mathrm{~g} \mathrm{~kg}^{-1}$ in the middle of the layers sampled from 0 to $40 \mathrm{~cm}$ depth in different treatments applied. The soil remediation had been done previously, raising the $\mathrm{pH}$ in water in the surface layer to near 6.0. In the period of 
conduction of the experiment fertilizations correction and maintenance were performed according to the recommendation for the crop.

Treatments consisted of four soil tillage systems before planting, applied in main plots and two grapevine rootstocks (VR 043-43 and Dog Ridge) applied as sub-plots. The tillage systems were: WP - without preparation; DR - making drains 80 cm deep, separated by a band of three meters; RI making ridges along the row $40 \mathrm{~cm}$ high and $90 \mathrm{~cm}$ wide; and DRRI - making of drains and ridges. The experimental design was a randomized split plot design with five replications.

Crop management consisted of weeding along the rows of culture and mowing between rows. Periodic spraying with fungicides was also made to control anthracnose. The experiment was installed in August 2007 and conduced for three vegetative cycles. The plants were pruned in August of each year, to $50 \mathrm{~cm}$ from ground level. In October / November of each year, we evaluated the percentage of dead plants or with characteristic foliar symptoms of decline. Here we present only the results of the evaluation performed in the last year, which can be considered the cumulative effect of the treatments. At the end of the third growing season, in June, $50 \times 50 \mathrm{~cm}$ square and $20 \mathrm{~cm}$ high soil monoliths were collected at layers $0-20$ and $20-40 \mathrm{~cm}$ deep in a pit open alongside a representative portion of the plant to determine the dry mass of roots after drying in an oven with forced air circulation at $70^{\circ} \mathrm{C}$ for $48 \mathrm{~h}$ and the presence of cysts of ground pearl associated with the roots. The results were subjected to the analysis of variance, and when significant differences observed for the $\mathrm{F}$ test, means were compared by the "t test" $(p<0.05)$. Roots from plants showing decline symptoms were collected for identification of pathogenic fungi present in the samples. The basic methodology is described in Garrido et al. (2004b).

\section{RESULTS AND DISCUSSION}

The cultivation on ridges significantly reduced the incidence of plants with symptoms of decline in both rootstocks studied (Table 1), but no significant effect was observed when treatment involved only drains. This result is probably related to the improvement in chemical and physical soil attributes and greater uniformity in values in depth with the making of ridges, creating more favorable conditions for root growth in the deeper layers (VEIGA et al., 2012). This can be proven by the greater dry mass of roots observed in this system in both layers sampled (Table 2). This effect was more pronounced on the middle diameter roots in the 0-20 $\mathrm{cm}$ layer, higher in rootstock VR 043-43, and on fine and medium diameter roots in the $20-40 \mathrm{~cm}$ layer, higher in the rootstock Dog Ridge, demonstrating a differential effect on rootstocks. The differences between the rootstocks root distribution is probably due to the root habit of each rootstock, since the VR 043-43 has greater tendency to concentrate the roots in the surface layers (DALBÓ et al., 2011). The same was observed in this experiment, where the amount of roots in the bottom layer $(20-40 \mathrm{~cm})$ was higher in the Dog Ridge relative to VR 043-43 in most root classes analyzed (Table 2).

Significant differences were observed in the number of cysts of ground pearl depending on the tillage systems, rootstocks and layers (Table 3). Such differences can be associated with the occurrence of a significant positive correlation between the number of cysts and the mass of medium, large and whole classes of roots (Table 4). There was, for some classes of roots, greater root growth provided by making ridges or drains, which should have favored the multiplication of this pest, but without result in loss of vigor and appearance of vine decline. Thus, the number of cysts of ground pearl had no significant correlation with the incidence of decline and death of plants under the conditions studied.

The incidence of decline and death of vine plants is associated, in addition to the ground pearl presence, to fungi and other soil stress factors for plants (CAVALCANTI et al., 2013; GARRIDO et al., 2004b; DALBÓ et al., 2007). In the present experiment, the symptoms of "black foot" caused by Cylindrocarpon destructans (or Neonectria liriodendri according to Haleen et al., 2007), characterized by the blackening of the roots of the exchange region, were quite common in plants showing symptoms of decline. Root samples analyzed in the laboratory allowed the isolation of some pathogenic fungi, especially Fusarium oxysporum, Cylindrocladium and Cylindrocarpon. Garrido et al. (2004b) found fungi of the genus Cylindrocladium, Phaeoacremonium, Botryosphaeria, Verticilium, Fusarium, Graphium, and Cylindrocarpon present in plants with symptoms of decline in vineyards of the "Serra Gaúcha" region. Thus, it is likely that more than one species of pathogenic fungus is contributing to the degradation of the vine root system.

The symptoms of vine decline occurring in southern Brazil are in many respects similar to diseases internationally known as "black foot", caused by Cylindrocarpon sp., and the "Petri disease" or "young vine decline", caused by 
Phaeoacremonium and Phaeoamoniella. These diseases have been reported in several countries, such as South Africa (HALEEN et al., 2006), New Zealand (MUNDY; MANNING, 2010), United States (GUBLER et al., 2004; SCHECK et al., 1998 ) and others, attacking mainly young plants. In general, these diseases are unimportant under normal growing conditions, but tend to appear in marginal soil conditions and plants subjected to some form of stress. These same fungi were found in Brazil associated with decline (GARRIDO et al., 2004a). It is likely that, in our conditions, damage to roots by the attack of the ground pearl, associated with deficiencies of aeration due to the clayey soil texture and high rainfall, are factors that enable the attack of pathogenic fungi that leads to the destruction of the root system. Thus, the most likely hypothesis is that soil preparation on ridges reduces the incidence of decline because of the unfavorable conditions for the fungi causing the disease without having a direct action on ground pearl.
In recent years several new vineyards in the State of Santa Catarina have been planted with ridges along the rows with the objective to reduce the incidence of grape decline problems. It has been observed that it has limited effect when traditional rootstocks are used, such as Paulsen 1103 or 10114. However, when associated with more resistant rootstocks, such as VR 043-43, it was an effective technique to reduce the incidence of decline, which confirms the results obtained in this study. Benefits of planting on ridges are expected for the same type of soil in which the experiment was conducted. In the case of less developed, gravelly soils, with high macroporosity, ridges are possibly unnecessary. However, most of the new vineyards are being established in areas more suitable for mechanization, where soils usually have high clay content and poor aeration. In these conditions, planting on ridges can be considered an important measure to reduce problems of plant mortality in the establishment of new vineyards in the Midwest of the State of Santa Catarina and others areas with similar soil conditions.

TABLE 1- Incidence of plants with symptoms of decline in two grapevine rootstocks according to the soil tillage in pre-planting.

\begin{tabular}{lcc}
\hline \multirow{2}{*}{ Pre-planting tillage } & Dog Ridge & VR 043-43 \\
\cline { 2 - 3 } Whithout preparation & Plants with symptoms of decline (\%) \\
Drain & $84 \mathrm{a} \mathrm{A}$ & $56 \mathrm{~b} \mathrm{~A}$ \\
Drain + ridge & $32 \mathrm{~b} \mathrm{~A}$ & $72 \mathrm{a} \mathrm{A}$ \\
Ridge & $4 \mathrm{a} \mathrm{B}$ & $12 \mathrm{a} \mathrm{B}$ \\
\hline
\end{tabular}

- Means followed by the same small letters in lines (between rootstock) and capital letters in columns (among tillage systems) do not differ by t-test for multiple comparisons of means (LSD).

- SD plots: $44.3 \%$; SD subplots: $28.2 \%$ 
TABLE 2- Dry mass of roots $\left(\mathrm{g} \mathrm{m}^{-3}\right)$ of rootstocks Dog Ridge and VR 043-43 at layers of 0-20 and 20-40 $\mathrm{cm}$ deep, according to the soil tillage in pre-planting.

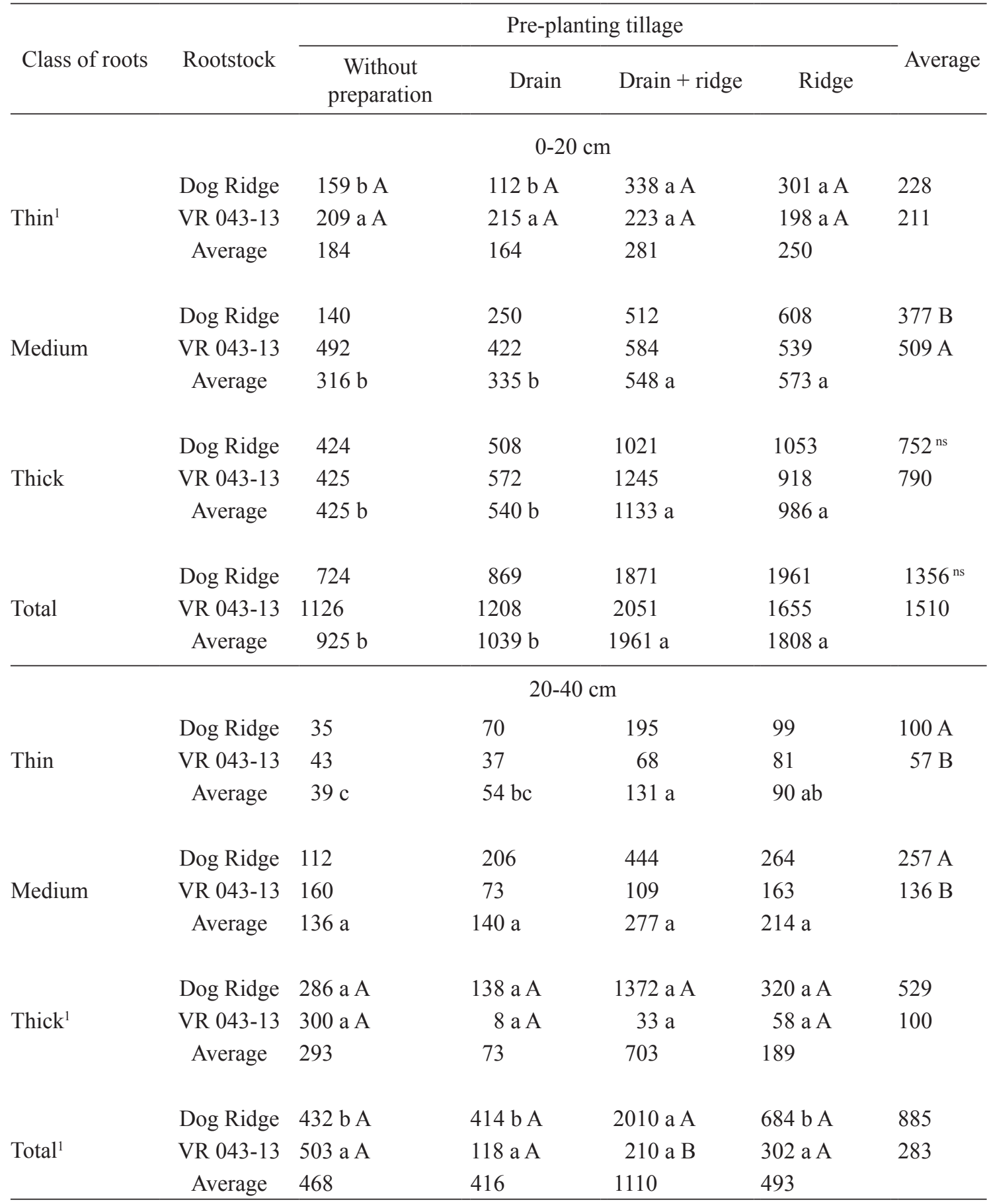

- Means followed by the same small letters in lines (among pre-planting tillage) and capital letters in columns (between rootstocks within each root class) do not differ by t-test for multiple comparisons of means (LSD). ${ }^{1}$ : interaction between pre-planting tillage and rootstock; ${ }^{\text {ns: }}$ no significant differences.

- SD for 0-20cm layer: Thin: SD plots $=20.2 \%$; SD subplots $=18.8 \%$; Medium: $\mathrm{SD}$ plots $=23.9 \%$; SD subplots $=22.6 \%$; Thick: SD plots $=31.3 \%$; SD subplots $=30.1 \%$; Total: $\mathrm{SD}$ plots $=21.9 \%$; SD subplots $=21.8 \%$.

- SD for 20-40cm layer: Thin: SD plots $=26.9 \%$; SD subplots $=28.5 \%$; Medium: $\mathrm{SD}$ plots $=37.6 \%$; SD subplots $=39.8 \%$; Thick: SD plots $=65.9 \%$; SD subplots $=58.1 \%$; Total: SD plots $=41.3 \%$; SD subplots $=41.0 \%$. 
TABLE 3- Number of ground pearl cysts associated with the roots of two grapevine rootstocks according to the soil tillage in pre-planting and layer sampled.

\begin{tabular}{|c|c|c|c|c|c|c|}
\hline \multirow{3}{*}{ Pre-planting tillage } & \multicolumn{5}{|c|}{ Layer } & \multirow[b]{3}{*}{ Average } \\
\hline & \multicolumn{3}{|c|}{$0-20 \mathrm{~cm}$} & \multicolumn{2}{|c|}{$20-40 \mathrm{~cm}^{1}$} & \\
\hline & Dog Ridge & VR 043-43 & Average & Dog Ridge & VR 043-43 & \\
\hline Without preparation & 1040 & 880 & $960 \mathrm{~A}$ & 276 a B & 312 a A & 294 \\
\hline Drain & 516 & 604 & $560 \mathrm{BC}$ & 228 a B & 16 a A & 122 \\
\hline Drain + ridge & 1004 & 676 & $840 \mathrm{AB}$ & 960 a A & $108 \mathrm{~b} \mathrm{~A}$ & 534 \\
\hline Ridge & 752 & 256 & $504 \mathrm{C}$ & 120 a B & 148 a A & 134 \\
\hline Average & $753^{\mathrm{ns}}$ & 604 & & 396 & 146 & \\
\hline
\end{tabular}

- Means followed by the same small letters in lines (between rootstocks within each pre-planting tillage) and capital letters in columns (among pre-planting tillage) do not differ by t-test for multiple comparisons of means (LSD). ${ }^{1}$ : interaction between pre-planting tillage and rootstock; ${ }^{\text {ns: }}$ no significant differences.

- 0-20cm layer: SD plots $=29.9 \%$; SD subplots $=32.3 \% ; 20-40 \mathrm{~cm}$ layer: $\mathrm{SD}$ plots $=57.5 \%$; SD subplots $=67.1 \%$

TABLE 4- Pearson correlation coefficients ( $\mathrm{r}$ ) between dry weight of roots and number of ground pearl cysts associated with classes of roots of rootstock Dog Ridge at layers of 0-20 and 20-40 cm deep.

\begin{tabular}{lcc}
\hline \multirow{2}{*}{ Root class } & \multicolumn{2}{c}{ Layer sampled } \\
\cline { 2 - 3 } & $0-20 \mathrm{~cm}$ & $20-40 \mathrm{~cm}$ \\
\hline Thin & $0.0387 \mathrm{~ns}$ & $0.2349 \mathrm{~ns}$ \\
Medium & $0.0213 \mathrm{~ns}$ & $0.5053 * *$ \\
Thick & $0.1083 \mathrm{~ns}$ & $0.4430 * *$ \\
Total & $0.1011 \mathrm{~ns}$ & $0.5655 * *$ \\
\hline
\end{tabular}

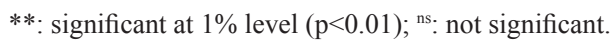

\section{CONCLUSIONS}

The making of ridges reduces the incidence of decline and death of plants of grapevine rootstocks in a clayey Oxisol;

Root growth of rootstocks is favored by making ridges and / or drains;

The number of ground pearl cysts is little affected by the making of drains or ridges in preplanting of rootstocks, and is not correlated with the incidence of decline and death of plants.

\section{REFERENCES}

BOTTON M.; COLlETA, V.D. Avaliação da resistência de cultivares de Vitis rotundifolia à perolada-terra (Hemiptera: Margarodidae) na região sul do Brasil. Acta Scientiarum Agronomy, Maringá, v. 32, n. 2, p. 213-216, 2010.

BOTTON, M.; HICKEL, E.R.; SORIA, S.J.; TEIXEIRA, I. Biologia e controle da pérola-daterra Eurhizococcus brasiliensis (Hempel, 1922) (Hemíptera: margarodidae) na cultura da videira. Bento Gonçalves: Embrapa Uva e Vinho, 2000. 23 p. (Circular Técnica, 27).
BOTTON, M.; TEIXEIRA, I.; BAVARESCO, A.; PASTORI, P.L. Use of soil insecticides to control the Brasilian ground pearl (Hemiptera: Margarodidae) in vineyards. Revista Colombiana de Entomologia, Bogotá, v. 36, n. 1, p. 20-24, 2010.

CAVALCANTI, F.R.; BUENO, C.J.; ALMANÇA, M.A.K. Declínio e Morte de Plantas de Videira. Bento Gonçalves: Embrapa Uva e Vinho, 2013.40p. (Documentos, 82).

CONRADIE, W.J.; CAREY, V.A.; BONNARDOT, V.; SAAYMAN, D.; SCHOOR, H. Effect of different environmental factors on the performance of Sauvignon Blanc grapevines in the Stellenbosch/ Durbanville Districts of South Africa. I. Geology, climate, phenology and grape composition. South Africa Journal of Enology and Viticulture, Stellenbosch, v.23, n.2, p.78-91, 2002. 
DALBÓ, M.A.; ARIOLI, C.; LOPES DA SILVA, M.; ANDRADE, E.R. Resistência de portaenxertos ao declínio e morte de plantas de videira. In: CONGRESSO BRASILEIRO DE FRUTICULTURA, 22., 2012, Bento Gonçalves. Anais... Bento Gonçalves: Sociedade brasileira de fruticultura, 2012. v. 1.

DALBÓ, M.A.; PERUZZO, E.L. SCHUCK, E. Alternativas de manejo para o controle do declínio da Videira. Agropecuária Catarinense, Florianópolis, v. 20, n.1, p. 58-61, 2007.

DALBÓ, M.A.; VEIGA, M.; GARDIN, J.P.P. Desenvolvimento do sistema radicular de videira em função de porta-enxertos e de atributos físicos e químicos do solo. Agropecuária Catarinense, Florianópolis, v. 24, n. 1, p. 59-63, 2011.

EMBRAPA - Empresa Brasileira de Pesquisa Agropecuária. Centro Nacional de Pesquisa de Solos. Solos do Estado de Santa Catarina. Rio de Janeiro: EMBRAPA/CNPS, 2004. 1 CD-ROM.; mapa color. (Boletim de Pesquisa e Desenvolvimento, 46).

GARRIDO, L.R., SÔNEGO, O.R.; URBEN, A.F. Cylindrocarpon destructans, causador do "pé-preto" da videira no Rio Grande do Sul. Fitopatologia Brasileira, Brasília, v. 19, n. 5, p. 548-550, 2004 a.

GARRIDO, L.R., SÔNEGO, O.R; GOMES, V.N. Fungos associados com o declínio e morte de videiras no Estado do Rio Grande do Sul. Fitopatologia Brasileira, Brasilia, v. 29, n. 3, p. 322-324. 2004 b.

GUBLER, W.D.; BAUMGARTNER, K.; BROWNE, G.T.; ESKALEN, A.; ROONEY LATHAM, S.; PETIT, E.; BAYRAMIAN, L.A. Root diseases of grapevines in California and their control. Australasian Plant Pathology, Murdoch, v. 33, n. 2, p. 157-165, 2004.

HALEEN, F.; FOURIE, P.H.; CROUS, P.W. A review of black foot disease of grapevine. Phytopathologia Mediterranea, Firenze, v. 45, n. 1, p. 55-67, 2006.

HALEEN, F.; SCHOEURS, H.F.; GROENEWALD, J.Z.; REGO, C.; OLIVEIRA, H.; CROUS, P.W. Neonectria liriodendri sp. nov., the main causal agent of black foot disease of grapevines. Studies in Micology, Utrech, v. 55, n. 1, p. 227-234, 2007.
KIRCHHOF, G.; BLACWELL, J.; SMART, R.E. Growth of vineyard roots into segmentally ameliorated acidic subsoils. Plant and Soil, Crowley, v. 134, p. 121-126, 1991.

MUNDY, D.C.; MANNING, M.A. Ecology and management of grapevine trunk diseases in New Zealand: a review. New Zealand Plant Protection, Auckland, v. 63, p. 160-166, 2010.

MYBURGH, P.A.; MOOLMAN, J.H. Ridging - a soil preparation practice to improve aeration of vineyard soils. South African Journal of Plant and Soil, Stellenbosch, v. 8, n. 4, p. 189-193, 1991.

MUNDY, D.C.; MANNING, M.A. Ecology and management of grapevine trunk diseases in New Zealand: a review. New Zealand Plant Protection, Auckland, v. 63, p. 160-166, 2010.

SCHECK, H.; VASQUEZ, S.; FOGLE, D.; GUBLER, W.D. Grape growers report losses to black foot and grapevine decline. California Agriculture, Richmond, v. 52, n. 4, p. 18-23, 1998.

SCHUCK, E.; DALBÓ, M.A.; ROSIER, J.P.; DUCROQUET, J.P. Porta-enxertos para a cultura da Videira. In: IV Enfrute, Fraiburgo, SC. Anais. Caçador-SC, Epagri, 2001. p. 122-132.

SOIL SURVEY STAFF. Keys to Soil Taxonomy. 10th ed. Washington: US Department of Agriculture - Natural Resources Conservation Service, 2006.

VEIGA, M.; DALBÓ, M.A.; DAMBROS, R.N.; PANDOLFO, C.M. Atributos químicos de um Nitossolo Vermelho seis anos após a confecção de camalhões e drenos para implantação de portaenxertos de videira. In: Reunião Sul-Brasileira de Ciência do Solo, 2012, Lages. Resumos. Lages: SBCS-NRS, 2012. p. 429-431. In: http://www.sbcsnrs.org.br/rsbes/docs/IX_RSBCS_2012_Anais.pdf

WHEATON, A.D.; MCKENZIE, B.M.; TISDALL, J.M. Management to increase the depth of soft soil improves soil conditions and grapevine performance in an irrigated vineyard. Soil and Tillage Research, Florence, v. 98, n. 1, p. 68-80, 2008. 